\section{New Associate Editor}

\author{
Katalin Mészáros Szécsényi
}

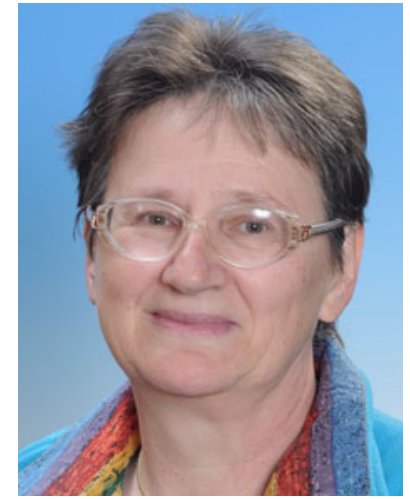

Name: Katalin Mészáros Szécsényi Year and place of birth: 1952, Mol, Yugoslavia

\section{Education and scientific degree}

University of Novi Sad, Faculty of Sciences (1974), M.Sc. (1982), Ph.D. (1991). Full Professor (2004).

\section{Workplaces}

University of Sciences of Novi Sad, Faculty of Sciences, Institute of Chemistry (1975-2002), Faculty of Sciences, Department of Chemistry, Biochemistry and Environment, E-mail:mszk@uns.ac.rs,mszk@EUnet.rs

K. Mészáros Szécsényi $(\bowtie)$

Department of Chemistry, Biochemistry and Environmental

Protection, Faculty of Sciences, University of Novi Sad,

Trg Dositeja Obradovića 3, 21000 Novi Sad, Serbia

e-mail:mszk@uns.ac.rs

\section{Short professional biography}

Until 1991, the main research interest: the study of thermodynamics of reactions in non-aqueous and aqueous molten salts applying electrochemical methods.

1992-1993: post-doctorial studies at the Technical University in Budapest, at Institute for General and Analytical Chemistry under supervision of professors F. Paulik, G. Pokol and S. Gal. Field: thermal analysis.

Present activity: synthesis and characterization of coordination compounds, thermoanalytical investigations of polymers and other compounds.

Co-author of over 70 scientific articles and a great number of scientific contributions at the national and international conferences. In the last 5 years published over 25 articles in journals from the SCI list. The co-authored articles were cited (without auto-citations) over 140 times. Participated in the study of many national scientific projects.

\section{University textbooks}

1. Dr Katalin Mesaroš Sečenji and Dr Ištvan Žigrai, "Basic Principles of Qualitative Analytical Chemistry", Series: University textbooks, 119, Faculty of Sciences, Novi Sad, 2000 (in Serbian).

2. Dr Katalin Mészáros Szécsényi: "Analytical Chemistry-Application of Chemical Equilibria to Qualitative Analytical Chemistry", Series: University textbooks, 188, Faculty of Sciences, Novi Sad, 2010 (in Serbian).

3. Dr. Mészáros Szécsényi Katalin, "A minőségi kémiai analízis alapjai Atlantis", 1999. (Supplement literature for teachers and students of second-grade schools, in Hungarian). 
4. Dr Terezija Šuranji and Dr Katalin Mesaroš Sečenji, "Practical Instructions for Qualitative Chemical Analysis" (Manual for internal use, in Serbian), Faculty of Sciences, Novi Sad, 1976.

\section{International scientific/professional activity}

Budapest University of Technology, Faculty of Chemical Technology from 1992.

Helsinki University of Technology, Department of Chemical Technology, 2000-visiting researcher.

Budapest University of Technology and Economy, Faculty of Chemical Technology and Biotechnology, 2003 (Domus Hungarica) — visiting professor.

Prince of Songkla University, Hatyai, Faculty of Science, 2008 (university collaboration).

Institute of Macromolecular Chemistry, Prague, 2010.

\section{CEEPUS II:}

AGH University of Science and Technology, Faculty of Materials Science and Ceramics, Krakow, 2009, 2011. University of Pardubice, Faculty of Chemical Technology, Pardubice, 2010.

Many times invited lecturer at conferences of Serbian and Hungarian Chemical Societies.

\section{Membership}

Serbian Chemical Society.

Chemical Society of Vojvodina.

Public Board of the Hungarian Academy of Sciences.

Working Committee on Thermoanalytical Section of the Hungarian Academy of Sciences.

\section{Current projects}

1. Project leader: "Design, synthesis, characterization and assessment of practical applications of coordination and organometallic compounds". Research project of the Ministry of Education and Science, Republic of Serbia, No. 142028.

2. "Multiscale structuring of polymer nanocomposites and functional materials based on different network precursors". Research project of the Ministry of Education and Science, Republic of Serbia, No. 142028.

3. "Transition metals complexes with some Schiff bases and pyrazole derivatives". Project financied by Provincial Secretary for science and technological development, Vojvodina, Novi Sad.

\section{List of 5 most important publications}

1. Mészáros Szécsényi K, Leovac VM, Jaćimović ŽK, Pokol G. Transition Metal Complexes with Pyrazole Based Ligands. Part 15. Cobalt(III)-, nickel(II)- and copper(II)-complexes with 3,5-dimethyl-1-thiocarboxamidepyrazole. J Therm Anal Calorim. 2003; 74: 943-7.

2. Leovac VM, Petković R, Kovács A, Pokol G, Mészáros Szécsényi K. Reactions of divalent transition metal halides with 3,5-dimethyl-1-(hydroxymethyl)-pyrazole and thermal characterization of the compounds. J Therm Anal Calorim. 2007; 89:267-75.

3. Jacimović ŽK, Leovac VM, Mészáros Szécsényi K, Giester G, Tomić ZD. Molecular and crystal structure of dichloroaqua(pyridoxal semicarbazone-ono)iron(iii) chloride and diaqua-sulphato (pyridoxal semicarbazone-ono)iron(II) complex. J Therm Anal Calorim. 2007; 90:549-55.

4. Holló B,Tomić Z, Pogány P, Kovács A, Leovac VM, Mészáros Szécsényi K. Transition metal complexes with pyrazole-based ligands. Part 28. Synthesis, structural, DFT and thermal studies of cadmium(II) halides and zinc(II) chloride complexes with 3,5-dimethylpyrazole-1-carboxamidine. Polyhedron. 2009; 28:3881-9.

5. Vujačić AV, Savić JZ, Sovilj SP, Mészáros Szécsényi K, Todorović N, Petković MŽ, Vasić VM. Mechanism of complex formation between $\left[\mathrm{AuCl}_{4}\right]^{-}$and L-methionine. Polyhedron. 2009; 28:593-9. 